\title{
The Comfort Burden of Seasonal Influenza and Influenza-like Disease in Hospitalized Children: 2015-2016 Season
}

\author{
Influenza Benzeri Bulgular ile Hastaneye Yatan Çocuk Hastalarda \\ Mevsimsel İnfluenza ve İnfluenza Benzeri Hastalığın Konfor Yükü: \\ 2015-2016 Sezonu
}

\author{
Kübra Aykaç,1, Sevgen Tanır Başaranoğlu', Onur Gözmen², Ayşe Filiz Yetimakman³, Özlem Tekşam4, Ateş Kara' \\ ${ }^{1}$ Department of Pediatric Infectious Diseases, Hacettepe University School of Medicine, Ankara, Turkey \\ ${ }^{2}$ Department of Pediatric Health and Diseases, Hacettepe University School of Medicine, Ankara, Turkey \\ ${ }^{3}$ Department of Intensive Care, Hacettepe University School of Medicine, Ankara, Turkey \\ ${ }^{4}$ Department of Pediatric Emergency, Hacettepe University School of Medicine, Ankara, Turkey
}

\begin{abstract}
Objective: The aim of this study is to investigate the comfort burden of hospitalized children admitted with influenza-like symptoms.

Material and Methods: We prospectively followed patients with influenza-like symptoms between December 2015 and April 2016 in our tertiary care hospital within the Global Influenza Hospital Surveillance Network $^{\circledast}$. The influenza polymerase chain reaction (PCR) was studied in the nasopharyngeal swab specimens taken from the participants, and the comfort burden of influenza on patients with or without influenza infection was evaluated.

Results: A total of 132 children with symptoms of influenza infection presented to the Hacettepe University İhsan Doğramacı Children's Hospital between December 2015 and April 2016 included in our study, and of these, the influenza virus was detected in 15 (11.3\%), whose median age was 2.3 years (minimum-maximum: 35 days-12.3 years), while no influenza virus was detected in 117 patients. The median age of these patients was 2.2 years (minimum-maximum: 22 days- 17.8 years). Similar findings were found in both groups in terms of hospitalization duration, school absenteeism, family night sleep disorder and parental work loss.
\end{abstract}

Özet

Giriş: Çalışmanın amacı, hastanemize influenza benzeri bulgularla gelen ve yatırılarak tedavi edilen çocuk hastaların konfor yüklerinin saptanmasıdır.

Gereç ve Yöntemler: Çalışmamızı, Aralık 2015 ve Nisan 2016 tarihleri arasında Global Influenza Hospital Surveillance Network ${ }^{\circledast}$ dahilinde prospektif olarak gerçekleştirildi. İnfluenza benzeri bulgular ile hastanemize yatırılan çocuk hastalar çalışmaya dahil edildi. Alınan nazofarengeal sürüntü örneklerinde, influenza polimeraz zincir reaksiyonu (PCR) çalışıldı. İnfluenza pozitifliği saptanan ve saptanmayan hastalar konfor yükleri açısından değerlendirildi.

Bulgular: Çalışmaya; Aralık 2015 ve Nisan 2016 tarihleri arasında influenza enfeksiyonu semptomları ile hastanemize yatışı yapılan 132 çocuk olgu alındı. Hastaların, 15 (\%11.3)'inde influenza virüsü izole edildi, bu hastaların ortanca yaşları 2.3 yıl (en küçük-en büyük; 35 gün-12.3 yıl), influenza saptanmayan 117 hastanın ortanca yaşı ise 2.2 yıl (en küçük-en büyük; 22 gün-17.8 yıl) idi. Hastanede yatış süreleri, okula devamsızlık süreleri, ailelerin gece uyku düzeni bozuklukları ve ebeveynlerin iş gücü kaybı açısından değerlendirildiğinde her iki grupta benzer farklılıklar tespit edildi.
Correspondence Address / Yazışma Adresi

Kübra Aykaç

Hacettepe Üniversitesi Tıp Fakültesi, Çocuk Enfeksiyon Hastalıkları

Bilim Dalı, Ankara-Türkiye

E-mail: kubraklnc.kk@gmail.com OCopyright 2017 by Pediatric
Infectious Diseases Society -Available online at www.cocukenfeksiyon.org OTelif Hakkı 2017 Çocuk Enfeksiyon Hastalıkları Derneği -Makale metnine www.cocukenfeksiyon.org web sayfasından ulaşılabilir 
Conclusion: Viral infections, especially influenza, are one of the leading causes of admission in children hospitals. Prospective studies involving larger patient groups are required to determine the comfort burden of such infections on affected individuals, families and society.

Keywords: Influenza, comfort burden

\section{Introduction}

Influenza (flu) is a respiratory disease that is caused by the influenza virus. The disease can be asymptomatic, or can present with mild symptoms, and extreme infections can lead to mortality. The virus may be transmitted by direct contact with those who are infected, through exposure to contaminated objects or via droplets. Most healthy adults can transmit the influenza virus to others one day before the onset of the disease to five or seven days after contracting the disease, though this period may be longer for children and people with weak immune systems (1). The disease is characterized by sudden onsets of high fever, muscular aches, headache, fatigue, coughing without mucus, sore throat, runny nose and nasal congestion. Aside from the fever, these symptoms typically persist for a week, while fevers often reach subfebrile levels after the second or third day (2). In a given season, it is not possible to predict the clinical severity of the disease, the onset or length of the influenza season, or the causative strain. For these reasons, the World Health Organization (WHO) recommends influenza monitoring within the Global Influenza Program, and publishes weekly epidemiological data on its website (www.who.int/ flunet) (3).

Influenza is associated with a range of respiratory (e.g. acute otitis media, pneumonia and sinusitis) and non-respiratory (e.g. febrile convulsions, encephalitis, transverse myelitis) complications. Moreover, the disease is associated with an increased use of antibiotics, which creates secondary complications (4, 5). Many countries have investigated the burden and costs of influenza infections, and an evaluation of such studies can help determine the necessary actions, vaccination and treatment strategies (6). The aim in this study is to reveal comfort burden on children admitted to our hospital with influenza-like symptoms during the 2015-2016 influenza season.

\section{Materials and Methods}

The study was approved by the Non-interventional Clinical Research Ethics Board of Hacettepe University (GO 15/766).

The study sample included 132 patients who were admitted to the Hacettepe University Ihsan Dogramaci Children's Hospital as inpatients between December 2015 and April 2016 within the Global Influenza Hospital Surveillance Network ${ }^{\circledR}$ (GIHSN).
Sonuç: Çocuk polikliniklerine başvuruların önde gelen nedenlerinden olan viral enfeksiyonların, özellikle de influenzanın bireylere, aileye ve topluma oluşturduğu konfor yükünün belirlenmesi için daha çok sayıda olgunun takip edildiği çalışmalara ihtiyaç vardır.

Anahtar Kelimeler: İnfluenza, komfor yükü

All patients were younger than 18 years of age and were Turkish citizens, and all patients had influenza-like symptoms (body temperature of $38^{\circ} \mathrm{C}$ or higher, coughing and/or throat ache) with onset in the last seven days. Patients with a minimum hospital stay of 24 hours were included in the study, while those staying in a nursery or kindergarten, and being discharged from hospital with in the last 30 days were excluded from the study.

Nasopharyngeal swab specimens were collected from patients with influenza-like symptoms, and the presence of the influenza virus was detected from a polymerase-chain reaction (PCR).

The following parameters were recorded in the assessment of comfort burden: age, gender, number of individuals with influenza symptoms in the household, number of siblings going to school, work status of parents, whether parents were able to take time off work, sleep quality of children and their parents at night, duration of school absenteeism, and vaccination status of children during the 2015 season.

The Global Influenza Hospital Surveillance Network ${ }^{\circledast}$ (GIHSN) is an international, active surveillance study involving hospitals in many countries that monitor the geographical distribution and epidemiology of influenza in consecutive influenza seasons. Turkey has been a partner of this network since 2005.

According to Ministry of Health of the Republic of Turkey sentinel influenza-like disease surveillance information for the 2015-2016 period, disease activity started on week 49 of 2015 and peaked in week 2 of 2016, while week 19 of 2016 was identified as the end of the influenza season (7). Based on this data, the period of the present study was defined as from December 2015 to April 2016.

SPSS version 20.0 software (SPSS, Inc., Chicago, IL, USA) was used for the data analysis, and median, and minimum-maximum values were used to summarize continuous variables, while frequency distributions were used to summarize categorical variables. As the data mostly consisted of categorical variables, a Chi-Square test was used to compare the variables between the influenza-positive and influenza-negative patients. A Fisher's Exact test was used to compare continuous variables, and a Mann-Whitney $U$ test was used to compare variables with an abnormal distribution, and when the number of cases was very small. $p$ values $<0.05$ were considered statistically significant. 


\section{Results}

As part of the GISHN, 132 children with influenza symptoms admitted to the Hacettepe University Ihsan Dogramaci Children's Hospital between December 2015 and April 2016 were included in the study. All patients had a minimum hospital stay of 24 hours.

Within the entire sample, 64 of the patients were female and 68 were male, and the median age was 2.2 years (minimum-maximum: 22 days- 17.8 years). The influenza virus was isolated from 15 patients (11.3\%) with a median age of 2.3 years (minimum-maximum: 35 days-12.3 years). The median age of the influenza-negative patients was 2.2 years (minimum-maximum: 22 days-17.8 years), and the influenza-positive and influenza-negative patients were similar in terms of age and gender $(p=0.62$ and $p=0.90)$ (Table 1$)$.

The patients were classified into two groups with respect to age. The influenza virus was detected in 12 of the 92 patients (13\%) aged 5 years or younger, while among the patients older than 5 years, the influenza virus was detected in three of the 40 patients $(7.5 \%)(p=0.5)$ (Figure 1$)$.

The highest number of patients ( $n=56,42.4 \%)$ with influenza-like symptoms were admitted in January. Influenza infections were detected in 66 percent of these patients (Figure 2).

Of the total, 57 influenza-positive patients (43\%) were found not to have an underlying disease, while those with an underlying disease were observed mostly with neurometabolic disease $(n=24)$, chronic lung disease $(n=13)$ and prematurity $(n=11)$. Of the total, seven influenza-positive patients (46.7\%) had no underlying disease, and eight influenza-positive patients had underlying diseases, including neurometabolic disease $(n=2)$, gastrointestinal disease $(n=2)$, hematologic-oncologic malignancy $(n=1)$, primary immunodeficiency $(n=1)$ and chronic renal failure $(n=1)$.

Furthermore, 50 influenza-negative patients $(42.7 \%)$ had no underlying disease, and 67 influenza-negative patients (57.3\%) had an underlying disease. The most common conditions were neurometabolic disease $(n=22)$, chronic lung disease $(n=12)$ and prematurity $(n=11)$.

Within one week prior to admission, nine of the $15(60 \%)$ influenza-positive patients had an individual with influenza symptoms in their household, and 59 of the 117 influenza-negative patients (50.4\%) had an individual with influenza symptoms in their household. In addition, nine influenza-positive patients $(60 \%)$ had a sibling of school age, whereas 64 influenza-negative patients (54.7\%) had a sibling of school age.

Among the influenza-negative patients, the median length of hospital stay was eight days (minimum-maximum: 1-41 days), and the median duration of school absenteeism was 10 days (minimum-maximum: 2-44 days). For influenza-posi- tive patients, the median length of hospital stay was six days (minimum-maximum: 2-20 days), and the median school absenteeism was eight days (minimum-maximum: 2-15 days). There was no statistically significant difference in the length of stay $(p=0.34)$ or school absenteeism $(p=0.09)$ among these groups.

Among the influenza-positive patients, nine (60\%) suffered nighttime sleep disturbance. Both the mothers and fathers of six patients had disturbed sleep at night. Only the mothers of four patients, and the fathers of three patients woke up at night for their children. Among the influenza-negative patients, 64 (54.7\%) experienced sleep disturbances at night. In 33 of the patients, both the mothers and the fathers experienced sleep disturbances at night; for 28 patients, only the mothers experienced sleep disturbance at night; and for one patient, only the father experienced sleep disturbance at night.

None of the mothers of influenza-positive patients were employed, whereas only one of the fathers was unemployed. During the hospital stay of the influenza-positive patients, only five fathers who were employed (35.7\%) took leave from work. Among the influenza-negative patients, 100 mothers were unemployed, whereas only one father was unemployed. For the influenza-negative patients, all mothers were on leave from work, whereas 39 fathers were on leave from work.

None of the patients had had a seasonal flu vaccination in 2015 , and no statistically significant difference in the comfort burdens of influenza-positive patients and influenza-negative patients was noted.

An evaluation within 48 hours of admission showed that 29 patients $(22 \%)$ received empirical oseltamivir treatment, and influenza virus was detected in six of these patients (20.6\%). The median length of stay was seven days (minimum-maximum: 3-15 days) for patients that received antiviral treatment, and five days (minimum-maximum: 2-20 days) for patients that did not receive antiviral treatment $(p=0.35)$. All patients received antibacterial treatment after being admitted to the hospital, and the antibacterial treatment was discontinued for only one patient who tested positive for influenza infection.

\section{Discussion}

A significant number of studies have aimed to assess the impact of influenza on children, although only a limited number have focused on the burden of influenza on patients, the family and society (5). A literature search found no previous studies focusing on the burden of influenza in Turkey. The current study comprises only hospitalized children, which prevents us from evaluating the actual burden of influenza.

The influenza virus was isolated in 15 patients (11.3\%) with influenza-like symptoms, and the median age of these patients was 2.3 years (minimum-maximum: 35 days- 12.3 years). Consistent with our study, Center for Disease Control and Pre- 
Table 1. Demographic and clinical features of patients

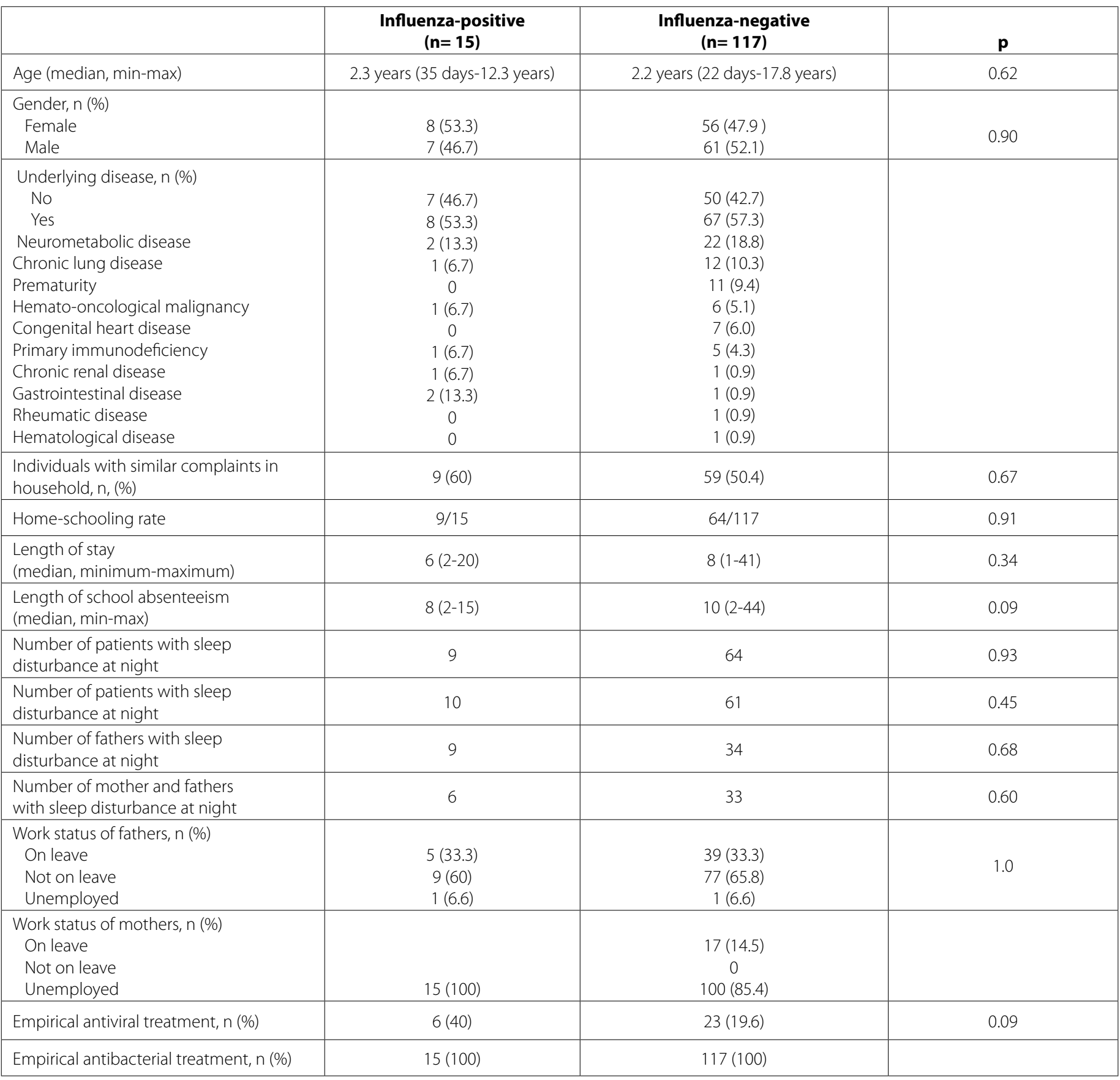

vention (CDC) data indicates that hospitalization due to influenza-related complications are most commonly seen in children, especially those aged under 5 years (8). As young patients require care, the hospitalization of such patients with influenza symptoms creates a social burden on the family.

Of the influenza-negative patients, 50.4 percent had a family member with influenza symptoms, and of the influenza-positive patients, nine of the $15(60 \%)$ had a family member with influenza symptoms. The CDC recommends separating the per- sonal items of affected individuals, such as bedrooms, towels and mugs, but with children it is not always possible to ensure these measures in a home environment (9).

Among the influenza-positive patients, only five fathers (35.7\%) were able to take leave from work, and all mothers were housewives. Of the influenza-negative patients, 17 were working mothers and all were on leave; while 39 fathers (33.6\%) were on leave. Various earlier studies have shown that influenza is a major factor in the loss of workforce $(10,11)$. Esposito et 


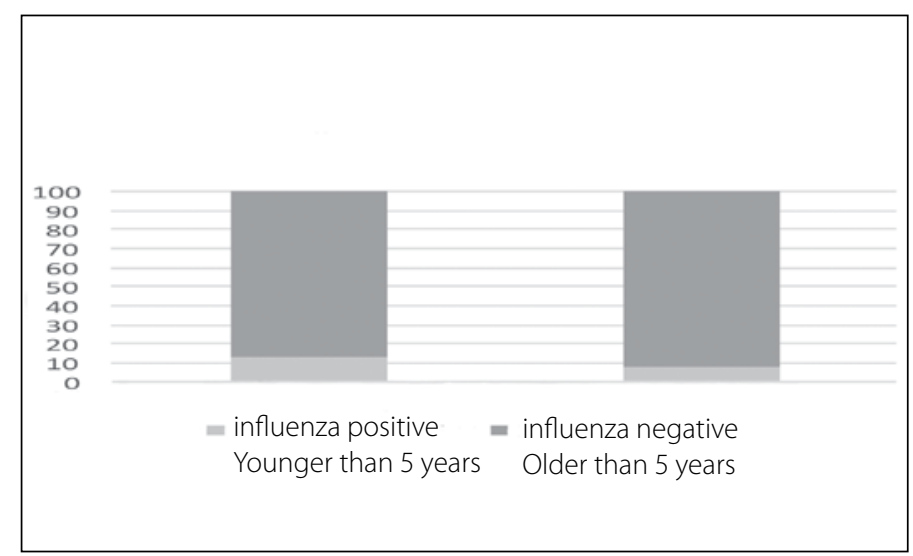

Figure 1. Distribution of influenza detection rates by age.

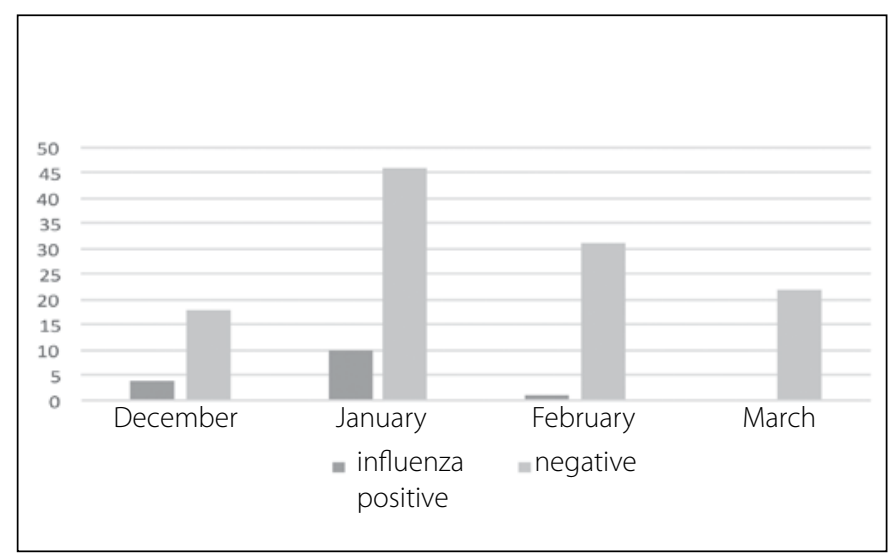

Figure 2. Distribution of polymerase chain reaction $(P C R)$ results in respiratory tract samples by months.

Tablo 2. Comparison of sleep quality between different influenza types

\begin{tabular}{|l|c|c|}
\hline & $\begin{array}{c}\text { Influenza } \\
\text { A-positive } \\
\text { (n= 13) }\end{array}$ & $\begin{array}{c}\text { Influenza } \\
\text { B-positive } \\
\text { (n= 2) }\end{array}$ \\
\hline $\begin{array}{l}\text { Number of patients with sleep } \\
\text { disturbance at night }\end{array}$ & 7 & 2 \\
\hline $\begin{array}{l}\text { Number of mothers with sleep } \\
\text { disturbance at night }\end{array}$ & 8 & 2 \\
\hline $\begin{array}{l}\text { Number of fathers with sleep } \\
\text { disturbance at night }\end{array}$ & 6 & 0 \\
\hline $\begin{array}{l}\text { Number of mother and fathers } \\
\text { with sleep disturbance at night }\end{array}$ & 6 & 0 \\
\hline
\end{tabular}

al., investigating the socio-economic impact of the respiratory syncytial virus (RSV) and the influenza virus on children and the household, found that the incidences of missed work days for mother or fathers was higher in influenza-positive cases (11). In the present study, almost all of the mothers, and more than 30 percent of the fathers, took leave from work to care for their children. In this regard, vaccinating children may be advantageous.

Sleep deprivation affects quality of life and causes infectious diseases to follow a worse progression. Sleep-wake cy- cles are associated with infectious diseases. Given its effect on cytokine secretion, sleep is known to be crucial for a healthy immune system, and sleep deprivation is known to reduce the production of influenza antibodies $(12,13)$. Bettis et al. reported that oseltamivir reduces the time to return to the pre-illness levels of sleep, and therefore, helps to decrease the overall burden of influenza on society (14). In the current study, nine patients with influenza (60\%) experienced sleep disturbances at night, 10 mothers (71.4\%) and nine fathers (60\%) experienced sleep disturbances at night, and both the mothers and fathers of six patients (40\%) experienced sleep disturbances at night. Our study indicates that influenza infection results in sleeping problems in more than 50 percent of the families (Table 1,2).

Influenza infection is an important factor in school absenteeism among children. In the current study, the median school absenteeism was eight days (minimum-maximum: 2-15 days) for influenza-positive patients, and 10 days (minimum-maximum: 2-44 days) for influenza-negative patients. King et al. explored the direct and indirect effects of influenza vaccination on school absenteeism, and found that each 20 percent increase in influenza vaccination rates is associated with a 4 percent reduction in school absenteeism during periods of influenza outbreak (15). In this study, none of the patients with influenza was vaccinated prior to the influenza season. The CDC suggests that seasonal influenza vaccines represent the best method of protection against influenza in children, and the vaccination of parents and caregivers is equally important for disease management (8). As reflected in our study, influenza infections, when compared to the cost of vaccinations, bring about a significant comfort burden on families and society. Raising awareness among families may help increase vaccination rates, and childhood vaccinations should be recommended, independent of any underlying disease.

Prospective studies involving larger patient cohorts are required to determine the comfort burden of such infections on affected individuals, families and society.

Ethics Committee Approval: The study was approved by Hacettepe University Clinical Research Ethics Committee with decision numbered GO 15/766.

Informed Consent: Informed was received from the patients and parents.

Peer-review: Externally peer-reviewers.

Author contributions: Concept - AK; Design - KA; Data collection and Processing - OG, STB, AFY; Analysis and interpretation - AK, KA, STB, ÖT; Writing - KA; Confirmation - ÖT, AK

Conflict of Interest: No conflict of interest was declared by the authors.

Financial Disclosure: No financial supported. 


\section{References}

1. Available from: $h$ ttps://www.cdc.gov/flu/keyfacts.htm

2. Available from: http://www.who.int/topics/influenza/en/

3. Available from: $w$ ww.who.int/flunet

4. Fraaij PL, Heikkinen T. Seasonal influenza: the burden of disease in children. Vaccine 2011;29:7524-8.

5. Low D. Reducing antibiotic use in influenza: challenges and rewards. Clin Microbiol Infect 2008;14:298-306.

o. de francisco Shapovatova $N$, Donadel $M$, Jit $M$, Hutubessy R. A systematic review of the social and economic burden of influenza in low- and middle-income countries. Vaccine 2015;33:6537-44.

\begin{tabular}{|c|c|}
\hline 7. & $\begin{array}{l}\text { Avallable trom: http://WWW.thsk.gov.tr/dokumanlar/70-bulaşıcl- } \\
\text { hastalıklar-daire-başkanlığı-dökümanları.html }\end{array}$ \\
\hline 8. & Available from: http://www.cdc.gov/flu/protect/children.htm \\
\hline $\begin{array}{l}\text { 9. } \\
\text { Avallable from: http://WwW.cdc.gov/flu/pdt/freeresources/general/ } \\
\text { influenza_flu_homecare_guide.pdf }\end{array}$ \\
\hline
\end{tabular}

10. Esposito S, Gasparini R, Bosis $S$, et al. Clinical and socio-economic impact of influenza and respiratory syncytial virus infection on healthy children and their households. Clin Microbiol Infect 2005;11:933-6.

11. Helkkinen I, sivennolnen $H$, Peltola $V$, et al. Burden of Influenza In children in the community. J Infect Dis 2004;190:1369-73.

12. Krueger JM, Majde JA. Sleep and host defense. In: Kryger MH, Roth T, Dement WC (eds). (2011). Principles and practice of sleep medicine. St. Louis: Elsevier Saunders, 2014:193-201.

13. Irwin MR. Sleep and infectious disease risk. Sleep 2012;35:1025-6.

14. Bettis $R$, lacuzio D, Jung T, Fuchs $R$, Aultman R, Gyldmark M. Impact of influenza treatment with oseltamivir on health, sleepand daily activities of otherwise healthy adults and adolescents. Clin Drug Investig 2006;26:329-40.

15. King JC Jr, Beckett D, Snyder J, Cummings GE, King BS, Magder LS. Direct and indirect impact of influenza vaccination of young children on school absenteeism. Vaccine 2012;30:289-93. 